\title{
Arapaho Language
}

National Cancer Institute

\section{Source}

National Cancer Institute. Arapaho Language. NCI Thesaurus. Code C153838.

A Plains Algonquian language spoken by the Arapaho of Wyoming and Oklahoma. 